\title{
PERKAWINAN DALAM SEJARAH KEHIDUPAN KELUARGA JAWA 1920AN-1970AN
}

\author{
Mutiah Amini \\ Departemen Sejarah, Universitas Gadjah Mada
}

\begin{abstract}
Abstrak. Tulisan ini mendiskusikan tentang perkawinan keluarga Jawa dalam periode 1920an-1970an. Sebuah periode ketika perkawinan mengalami tarik menarik kepentingan, baik bagi perempuan sendiri, organisasi sosial-politik, maupun negara. Hal itu tampak melalui solusi atas permasalahan sosial yang muncul terkait dengan perkawinan. Perempuan memiliki cara sendiri untuk hadir di dalam mengatasi permasalahan tersebut. Demikian juga organisasi sosial-politik dan negara. Solusi atas permasalahan perkawinan, dengan demikian, menunjukkan bagaimana perempuan menarasikan dirinya sendiri, bagaimana pula sebenarnya perempuan dinarasikan oleh organisasi sosial-politik dan negara. Untuk menemukan realitas historis terkait dengan perkawinan di masa lalu, tulisan ini menggunakan data tertulis, baik buku, artikel, maupun gambar yang dihasilkan dari surat kabar dan majalah yang terbit dalam kurun waktu tersebut.
\end{abstract}

Kata-kata kunci: perkawinan, perempuan, Jawa

\begin{abstract}
This paper will discuss the Javanese family's marriage in the period between 1920's and 1970's. The marriage faces some interests comprising the women's interest, social-political organization's and nation's interest. This is seemed by the solution of the appeared social problem related to the marriage, social-political organization, and the nation. Therefore, women describe themselves, likewise women are described by social-political organization and the nation. To find the historical phenomena related to the past marriage, this paper used the written data like books, articles, and pictures produced by the newspaper and magazine which were published in this period.
\end{abstract}

Keywords: marriage, woman, Java

Rentang waktu antara tahun 1920an hingga tahun 1970an terjadi berbagai perubahan penting dalam kehidupan masyarakat. Dalam historiografi Indonesia, periode tersebut dikenal sebagai periode peralihan. Dimulai oleh berakhirnya kekuasaan kolonial, masuknya pendudukan Jepang, dan dimulainya periode kemerdekaan. Periode ini juga merupakan periode krusial di mana semua sendi-sendi kehidupan mengalami perubahan yang sedemikian rupa. Akhir kekuasaan kolonial telah memberikan fondasi pendidikan yang cukup kuat bagi masyarakat di Hindia Belanda. Pendidikan kemudian menjadi dasar dari lahirnya para pemikir awal dan dunia literasi, yang pada akhirnya melahirkan pemikiran-pemikiran baru dalam membangun ke-Indonesiaan. Demikian halnya dalam periode pendudukan Jepang. Pendudukan yang tidak begitu lama justru memberikan ruang berkembangnya organisasi sosial-politik, untuk melahirkan identitas bersama yang disebut Indonesia yang merdeka. Kondisi ini segera disusul dengan periode kemerdekaan, ketika masyarakat Indonesia kemudian ingin memberi arti bagi kemerdekaan yang baru mereka bangun.

Sementara itu bagi perempuan, periode peralihan merupakan periode yang penting karena pendidikan bagi perempuan yang telah dirintis dalam periode sebelumnya, pada tahun 1920an mulai menunjukkan hasilnya. Perempuan mulai berpikir tentang dirinya yang mereka 
ekspresikan di dalam tulisan-tulisan yang sudah mulai mereka publikasikan. Pemikiran yang sama mereka ekspresikan secara kolektif melalui pendirian kursus untuk perempuan atau perjuanganperjuangan lain bagi perbaikan kehidupan perempuan di ruang domestik maupun publik. Dari keseluruhan tema yang dapat diamati dari perubahan kehidupan perempuan dalam periode ini, tulisan ini secara spesifik ingin mendiskusikan tentang apa yang terjadi terkait dengan perkawinan. Hal ini penting karena permasalahan perkawinan, jarang diperhatikan di dalam kajian sejarah. Bahkan kajian sejarah perempuan sekalipun. Padahal, perkawinan tidak hanya bermakna sebagai sebuah institusi tempat mengikrarkan ikatan suamiistri antara laki-laki dan perempuan, tetapi juga sebuah ikrar untuk mengikatkan dua buah keluarga untuk menjadi satu. Di dalamnya kemudian terjadi berbagai negosiasi, tarik menarik kepentingan sosial, politik, maupun budaya. Dalam hal inilah kajian sejarah menjadi penting untuk mengkaji permasalahan ini.

Beberapa kajian dilakukan para peneliti untuk mencermati ikatan perkawinan, baik bentuk perkawinan yang ada maupun pembagian ruang sebagai konsekuensi perkawinan yang terjadi. Djajadiningrat-Niewenhuis, misalnya, mengamati perkawinan melalui ide ibuisme. Di dalam penelitian Djajadiningrat-Niewenhuis, dalam perkawinan seringkali terjadi pendomestikasian peran istri. Ide ibuisme terus menerus dijaga didalam kelompok sosial di dalam masyarakat Jawa, baik oleh masyarakat maupun negara. Akibatnya, seorang Ibu bisa mendapatkan sangsi dari masyarakat apabila ia dipandang tidak mampu menjalankan tugasnya sebagai seorang "Ibu" seperti yang diharapkan oleh masyarakatnya (DjajadiningratNiewenhuis, 1992:43-51). Dalam kajian lain, ide tentang ibuisme bisa juga muncul bukan oleh konstruksi masyarakat, tetapi oleh kebijakan negara. Dalam hal ini, Julia Suryakusuma, misalnya, mencermati ide ibuisme pada masa Orde Baru, di mana ibuisme merupakan produk dari otoritas Negara yang demikian kuat dalam mengatur kehidupan keluarga. Penguatan konsepsi tentang ibu tersebut muncul, baik melalui pembentukan organisasi perempuan di semua sektor kerja laki-laki maupun melalui pembentukan organisasi sosial khusus perempuan di masyarakat (Suryakusuma, 1996: 92-119), Akibatnya, konstruksi tentang ibu yang telah terbentuk seabad sebelumnya menjadi semakin kuat dalam kehidupan keluarga Jawa sesudah Indonesia merdeka.

Sementara itu Geertz (1982), LocherScholten (1992), dan Amini (2013) mencoba mencermati perkawinan dalam cara pandang yang berbeda. Ketiganya melihat bahwa perkawinan merupakan sebuah fenomena historis, dimana kondisi tempat dan waktu yang berbeda akan menunjukkan pola yang berbeda pula. Dalam hal ini, ketiganya sepakat bahwa sekalipun perkawinan merupakan hal yang menyangkut kehidupan privat, tetapi ia dipengaruhi pula oleh kebijakan publik. Pengaruh sosial, ekonomi, dan politik demikian besarnya berpengaruh di dalam fenomena ini. Berdasarkan pemikiran tersebut, tulisan ini kemudian ingin mencermati lebih mendalam cara masyarakat Jawa memahami perkawinan, baik secara individual maupun kolektif dalam kurun waktu yang panjang, yaitu dari akhir masa kolonial, Jepang, hingga awal kemerdekaan. Melalui cara pandang ini, bagaimana perempuan Indonesia menarasikan dirinya sendiri dan bagaimana pula perempuan dinarasikan akan terlihat. 


\section{DARI USIA DINI HINGGA POLIGAMI}

Berbagai permasalahaan perkawinan muncul sepanjang waktu 1920an hingga 1970an. Permasalahan-permasalahan tersebut terkait dengan perkawinan dini yang banyak terjadi di dalam kehidupan masyarakat, adanya perselingkuhan, hingga poligami. Permasalahan tentang pernikahan dini, misalnya, diungkapkan oleh Abdoerachman, seorang aktivis perempuan yang merasa bahwa pernikahan dini sudah merupakan permasalahan serius di masyarakat. Abdurrachman kemudian mengungkapkan kegelisahan tersebut melalui sebuah opini yang ia tuliskan dan publikasikan melalui surat kabar Putri Mardika, yang terbit sejak tahun 1917 dan banyak mengangkat tema seputar permasalahan perkawinan. Ungkapan kegelisahan Abdoerachman tampak dalam kutipan berikut ini.

"Kami akan sangat gembira jika
saja perempuan di bawah usia 18
tahun dilarang menikah... Jika
perkumpulan kita dapat
membantu mengakhiri semua ini,
dan secepatnya, suatu kebiasaan
lama yang membawa para gadis
yang baru saja meninggalkan
masa kanak-kanaknya untuk
menikah dengan seorang lelaki
yang tidak dikenalnya dan bahkan
tidak akan pernah dapat
mencintainya...." (Abdoerachman
dalam Vreede-De-Steurs,
2008:85)

Melalui tulisan tersebut, Abdoeracahman ingin mengungkapkan bahwa selama ini perkawinan dengan pengantin perempuan berusia di bawah 18 tahun marak terjadi dalam kehidupan masyarakat Jawa. Selain karena belum siapnya perempuan dari segi usia di dalam perkawinan yang mereka bangun, juga karena perempuan biasanya menikah karena perjodohan yang dilakukan oleh kedua orang tuanya. Akibatnya para perempuan yang baru saja lepas dari usia anak-anak akan tidak siap membangun keluarga baru. Kondisi ini akan sangat rentan terjadinya permasalahan sosial, jika tidak segera diatasi. Sebagai seorang aktivis perempuan, Abdoerachma merasa wajib mengungkapkan kegelisahan ini untuk mengubah kondisi yang salama ini sudah berlangsung secara turun temurun.

Apabila dicermati secara teliti, dari penerbitan surat kabar dan majalah dalam periode 1920-1950, ungkapan tentang kegelisahan maraknya pernikahan dini banyak sekali terungkap. Pada tahun 1939, misalnya, muncul pula ungkapan seorang perempuan (yang tidak menyebutkan namanya) yang mengungkapkan secara spontan permasalahan perkawinan yang ia alami melalui surat kabar Pesat yang terbit pada tahun 1939. Pesat merupakan surat kabar milik SK Trimurti, yang untuk pertama kalinya memuat ungkapanungkapan perempuan tentang permasalahan perkawinan yang mereka alami, tanpa mewajibkan pengirimnya mencantumkan identitas dirinya. Pengirim hanya perlu menyampaikan identitas diri pada redaksi, dan redaksi akan menyembunyikan siapa sebenarnya penulis ungkapan-ungkapan tersebut. Salah satu ungkapan perempuan yang termuat di dalam Pesat tampak dari kutipan berikut ini.

\footnotetext{
"Saja seorang perempuan jang ditinggalkan soeami, dengan djalan thalak. Doea boelan soedah berlaloe hingga kini, saja tinggal di roemah dengan empat anak. Sembilan tahoen jang laloe, saja dikawinkan oleh iboe bapa saja dengan soerang anak moeda jang tjakap. Katanja ini anak moeda akan djadi teman, pelindoeng dan pemimpin saja selama hidoep.
} 
Saja tjinta betoel kepada soeami saja. Sembilan tahoen kami hidoep bersama, sehingga kami mempoenjai 4 anak. Beberapa tahoen jang laloe ini, kami pindah ke Semarang. Dalam permoelaanja, keadaan kami biasa sadja. Setelah soeami saja masoek djadi lid dari soeatoe koempoelan, moelailah dia poelang djaoeh2 malam, kadang-kadang djam 2 malam baroe dia poelang; kalau saja bertanja, katanja dari roemah perkoempoelan. Saja insjaf kesalahan saja, soeami saja koebiarkan berhoeboengan kemana-mana dengan ta' ada pengawasan.'(Pesat, 9 Februari 1939, Tahun Pertama, Nomor 20)

Tulisan ini secara personal menggambarkan ungkapan hati seorang perempuan, yang kemudian ditinggalkan oleh pasangannya. Dari ungkapan tersebut tersirat bahwa perempuan yang menulis juga merupakan korban dari adanya pernikahan dini dan penikahan yang dipaksakan oleh orang tua. Munculnya permasalahan tentang perkawinan dini, menjadi inspirasi penting bagi Raden Soetomo untuk menulis dan mendivinisikan tentang apa yang disebut dengan pernikahan dini. Raden Soetomo mendevinisikan pernikahan dini melalui batasan terhadap apa yang disebut anak-anak dan dewasa sehingga seorang perempuan dianggap pantas untuk menikah. Menurut Raden Soetomo, disebut sebagai anak-anak apabila mereka belum haid. Dengan demikian, jika seorang anak perempuan telah mendapatkan menstruasi, ia akan dianggap sebagai seorang dewasa, bukan anak-anak lagi dan ia kemudian dapat menikah (Soetomo, 1928).

Tentu saja, devinisi Raden Soetomo belum mewakili keinginan perempuan, tentang pembatasan usia anak perempuan yang akan menikah sehingga perkawinan dini tidak terjadi. Demikian halnya tentang poligami yang banyak terjadi. Hanya saja, perdebatan tentang pernikahan dini, tampak lebih menonjol diperbincangkan di dalam periode ini dibandingkan dengan permasalahan tentang perselingkuhan ataupun poligami. Keluarga Jawa tampaknya lebih permisif terhadap poligami, dan menganggap bahwa permasalahan ini merupakan permasalahan syariah agama, yang sudah baku. Sekalipun hal ini sebenarnya ditentang oleh para aktivis organisasi-organisasi perempuan muslim, yang justru melihat bahwa hukum perkawinan yang harus ditegakkan untuk melindungi perempuan, dari semua ras, agama, dan etnis adalah pernikahan monogami.

Atas segala permasalahan perkawinan yang belum terpecahkan, setidaknya hingga tahun 1930an, para perempuan kemudian berkumpul di Jakarta pada tanggal 16 September 1937. Hadir dalam pertemuan tersebut adalah perwakilan dari beberapa organisasi perempuan di Jawa. Mereka berkumpul di Sekolah Menengah Muhammadiyah di Jakarta untuk membicarakan pentingnya Indonesia memiliki peraturan perkawinan, yang dapat memuaskan masyarakat secara keseluruhan. Karena itu kemudian dibentuklah oleh organisasi-organisasi perempuan di Jawa sebuah Komite Perlindungan Kaum Perempuan dan Anakanak Indonesia (BPPIP, 1939). Pendirian komite yang dilakukan oleh perempuan menunjukkan komitmen aktivis organisasi sosial-politik untuk melindungi perempuan di dalam sebuah ikatan perkawinan. Beberapa aktivis yang hadir dalam pertemuan tersebut, tampak dari foto berikut ini. 


\section{Gambar 1}

Komite Penerimaan Konferensi Badan Perlindungan Perempuan Indonesia dalam Perkawinan Sumber: Boekoe Peringatan Konferensi Badan Perlindoengan Perempoean Indonesia dalam Perkawinan (BPPIP), 21-23 Juli 1939 di Maratam-Jogjakarta, hlm 7.

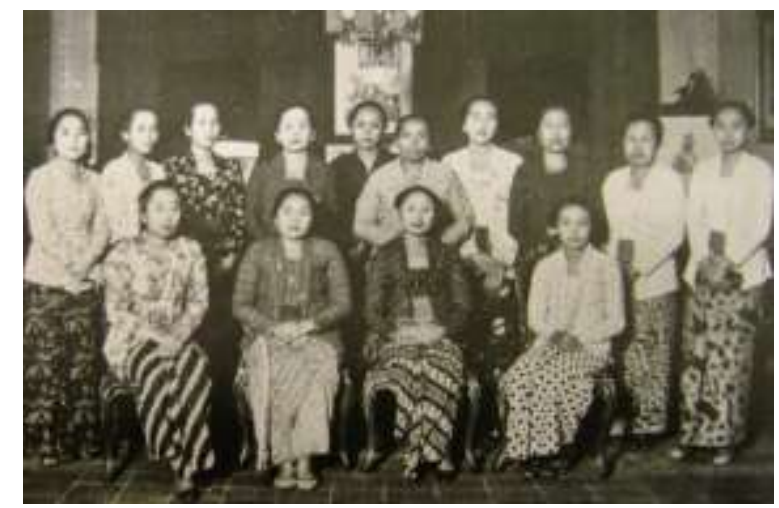

Selain melalui Komite Perlindungan Kaum Perempuan dan Anak-anak Indonesia, para aktivis perempuan juga melakukan pembahasan terus menerus terkait dengan aturan perkawinan yang perlu diperjuangkan oleh para perempuan. Pada bulan Juli 1939 diselenggarakan Konferensi Badan Perlindungan Perempuan Indonesia dalam Perkawinan. Dalam konferensi tersebut ditampilkan pidato dari para aktivis perempuan. Nyonya $P$. Hadiwinoto, misalnya, berpidato tentang "Keadaan Perkawinan Bangsa Indonesia". Beberapa kasus sebagai bagian dari isi pidato Hadiwinoto adalah tentang perempuan yang mempunyai tiga orang anak kemudian diceraikan oleh suaminya, perempuan yang diceraikan suaminya padahal ia dalam keadaan sakit keras, istri yang diceraikan suami tanpa alasan yang jelas, perempuan yang dijodohkan oleh orang tuanya tetapi suaminya tidak menghendakinya. Sementara itu, dari segi latar berlakang suami yang menceraikan juga bermacam-macam, mulai dari juru tulis, ambtenar, hingga mandor (Haniwinoto, 1939).

Dari beberapa pidato yang muncul di dalam Konferensi Badan Perlindungan Perempuan Indonesia dalam Perkawinan, tampak sebenarnya bahwa mereka yang mempermasalahkan tentang perkawinan yang mereka alami adalah berasal dari strata sosial atas atau setidaknya dari mereka yang memiliki latar belakang pendidikan yang baik. Sebab hanya dari kalangan merekalah sebenarnya kesempatan untuk menjadi juru tulis, ambtenar, dan mandor muncul (Kartodirjo, dkk., 1987). Hal ini senada dengan ungkapan Soekarno di dalam Sarinah. Sindiran Soekarno adalah bahwa perempuan yang banyak bersekolah di sekolah-sekolah rumah tangga akan lebih "mondaine" atau lebih "mrijantun". Mereka bisa merasa lebih tinggi daripada perempuan-perempuan yang kurang mahir di dalam ilmu keperempuanannya. "Mereka mendidik gadis-gadis, supaja nantinja "laku" di kalangan kaum pemuda bangsawan dan hartawan, untuk dikawin, dan mendjadi "grande dame"(Soekarno, 1963).

Di sisi lain, permasalahan perkawinan juga seringkali muncul dari perempuan sendiri. Di dalam surat kabar Indonesia Raya terbitan tahun 1956, misalnya, Nazaruddin Latief, kepala Urusan Agama Djakarta Raya melaporkan bahwa telah ada 3 kasus di mana ada tiga perempuan yang yang melakukan pelanggaran KUHP (kriminal) di mana ia mengaku dirinya perawan dan wali atau 
ayahnya sendiri menguatkan keperawanannya, sedangkan sebenarnya ia pernah kawin, serta hubungan dengan suaminya yang lama belum diputus secara resmi. Satu diantara dua perempuan tersebut telah dijatuhi hukuman 2 bulan penjara oleh Pengadilan Negeri. Pelanggaran ini diketahui setelah datang pengaduan dari suami lama, dan yang menjadi kesulitan bagi para Naib ialah adanya pengakuan dari wali (Indonesia Raya, No. 152, Tahun VII, 6 Juli 1956).

Solusi atas permasalahan yang muncul dalam periode ini adalah perlunya dibentuk semacam marriage conselling. Marriage conselling ini merupakan satu bentuk usaha untuk mengatasi permasalahan terkait dengan perkawinan, bahkan terhadap permasalahan penyakit kelamin yang banyak muncul di masyarakat. Ide tentang marriage conselling dicetuskan oleh Sujadi, penasihat masalah kependukun ketika memberikan ceramah di depan para dokter pemberantas penyakit kelamin di DIY pada tahun 1970 (Berita Nasional, No. 272, Tahun VI, 29 Juli 1976, hlm. 2).

\section{REGULASI DAN \\ "INSTITUSIONALISASI" PERKAWINAN}

Dari berbagai permasalahan terkait dengan perkawinan, juga solusi yang kemudian dimunculkan oleh perempuan, baik secara individual maupun kelompok, pada akhirnya memaksa negara untuk hadir. Karena itu, pada tahun 1946 mulai muncul rancangan undang-undang perkawinan. Artinya, aturan tertulis tentang perkawinan mulai dibuat. Sebelum adanya aturan tertulis ini, segala hal terkait dengan perkawinan digunakan hukum adat dan hukum agama. Sementara itu, hukum tertulis baru berupa hukum perkawinan berdasarkan golongan, yaitu golongan Barat
(Eropa), Kristen, dan Cina. Pembuatan hukum perkawinan ini dilakukan untuk mengatasi permasalahan sosial yang selama ini muncul. Tentu saja, hukum perkawinan kemudian menjadi satu "institusi" yang sangat menarik karena hukum perkawinan ini harapannya bisa lintas etnis dan agama. Sayangnya, belum sempat hukum perkawinan ini diundangkan, telah timbul perdebatan di masyarakat karena berbagai permasalahan yang terakomodasi di dalamnya belum banyak menampung aspirasi perempuan berdasarkan permasalahan yang selama ini timbul.

Pada tahun 1954 permasalahan perkawinan kemudian dibicarakan secara luas oleh para aktivis perempuan, bersamaan dengan munculnya Rancangan Undang-Undang Perkawinan. Rancangan ini muncul atas usul inisiatif dari Nyonya Soemari, salah seorang aktivis permepuan. Di dalam rancangan ini, Nyonya Soemari mencoba menggabungkan antara kepentingan perempuan, kepentingan umat Islam, dan pemerintah. Menurut Nyonya Mahmudah-Mawardi, salah seorang aktivis yang juga hadir, rancangan ini dibuat dengan maksud untuk mengatur perkawinan bagi seluruh warga negara Indonesia dengan tidak membedakan golongan dan suku bangsa, dan tidak mengurangi hak tiap-tiap warga negara untuk kawin menurut agamanya masingmasing sesuai dengan dasar Pancasila. Permasalahan perkawinan poligami menurut pemikiran Nyonya MahmudahMawardi adalah bahwa poligami tidaklah dilarang. Akan tetapi, undang-undang harus memberikan sanksi yang cukup berat bagi tiap-tiap poligami yang sembarangan dilakukan. Adapun menurut Nyonya Soenaryo Mangoenpoespito, bahwa rancangan undang-undang atas usul Nyonya Soemari dan kawan-kawan merupakan undang-undang pokok dari bermacam-macam aturan perkawinan. 
Dengan adanya undang-undang ini, maka undang-undang pernikahan Islam akan menjadi undang-undang organik di samping undang-undang perkawinan agama lain dan undang-undang perkawinan mernurut hukum adat (Surya-Hadi, 1959:1-24). Sayangnya rancangan undang-undang ini juga belum berhasil diundangkan. Baru melalui Undang-Undang Perkawinan 1972 peraturan terkait perkawinan secara tertulis diberlakukan.

Di dalam Undang-Undang Perkawinan 1972, inti dari undang-undang adalah untuk menghormati semua agama, sehingga perkawinan menjadi sah dilakukan menurut hukum masing-masing agama dan kepercayaannya setelah mengikuti aturan yang tertuang di dalam Pasal 2 no. 1 undang-undang tersebut. Undang-undang ini secara detil mengatur tentang aturan berpoligami, soal putusnya perkawinan, dispensasi, izin kawin, dan aturan lain yang sebelumnya tidak diatur oleh negara (Sosroatmodjo dan Aulawi, 1975:40). Sejak diberlakukannya undang-undang 1972, maka tata cara pelaksanaan perkawinan diatur dalam peraturan perundangundangan tersendiri. Yang intinya, nikah yang dilakukan menurut agama Islam diawasi oleh Pegawai Pencatat Nikah. Talak dan rujuk diberitahukan kepada Pegawai Pencatat Nikah. Pegawai ini diangkat dan diberhentikan oleh Mentri Agama (Sosroatmodjo dan Aulawi, 1975:402). Perbedaan antara hukum nikah 1954 dan 1974 adalah bahwa hukum nikah 1954 merupakan peraturan yang berisi hukum formil. 1974 merupakan hukum materiil yang sebelumnya tidak dikenal bagi golongan Islam, karena bagi umat Islam hanya berlaku hukum adat. Adapun batasan usia nikah diatur secara tegas di dalam undangundang ini, yaitu bagi laki-laki setidaktidaknya berusia 19 tahun dan bagi perempuan setidak-tidaknya berusia 16 tahun (Sosroatmodjo dan Aulawi, 1975:44).
Sebagai satu bentuk penetapan atas undang-undang, pada tahun 1975 PBB ditetapkan menetapkan the International Woman's Year. Undang-undang perkawinan yang telah disyahkan pada hari Ibu di tahun 1972 didesak oleh organisasiorganisasi perempuan yang tergabung dalam Kowani, Perwari, Wanita Islam, dan KNKWI (Komisi Nasional Kesatuan Wanita Indonesia) untuk segera diikuti dengan peraturan pemerintah. Hasilnya, pada 1975 diundangkan Peraturan Pemerintah tentang pelaksanaan Undangundang No. 1 Tahun 1974 tentang Perkawinan. Butir yang dianggap penting tetapi belum masuk ke dalam peraturan tersebut adalah butir yang mengatur tentang penunjukkan terhadap pejabat yang berkewajiban mencegah berlangsungnya perkawinan yang tidak memenuhi syaratsyarat dan mengenai anak yang lahir di luar perkawinan (Sosroatmodjo dan Aulawi, 1975:48-49).

Melalui sistem pencatatan yang baru berdasarkan peraturan 1975, masih terdapat golongan-golongan msayarakat Indonesia yang belum mempunyai sistem pencatatan perkawinan, dengan kata lain mereka belum diatur dalam peraturan perundangundangan. Mereka itu terdiri dari orangorang Kristen di Sumatra, Kalimantan, Bali, Busa Tenggara Barat, Nusa Tenggara Timur, sebagian besar Sulawesi, sebagian besar Maluku dan Irian Jaya. Begitu pula orang-orang yang beragama Budha, Hindu, dan lain-lain. Pencatatan perkawinan bagi mereka ini dilakukan di Kantor Catatan Sipil berdasarkan ketentuan-ketentuan Pasal 3 sampai dengan Pasal 9 Peraturan Pemerintah. Dan memang peraturan pemerintah ini dimaksud untuk mengisi kekosongan tersebut (Sosroatmodjo dan Aulawi, 1975:52). 


\section{PENUTUP}

Permasalahan sosial berulangkali muncul dalam periode 1920an-1970an. Berbagai solusi atas permasalahan itu pun dihasilkan, baik secara individu maupun kolektif. Permasalahan paling banyak diungkap adalah terkait pernikahan dini, perselingkuhan di dalam perkawinan, poligami, hingga akibat yang ditimbulkan dari perkawinan yang tidak diatur berupa penyakit kelamin. Permasalahanpermasalahan tersebut berulangkali muncul di dalam pemberitaan surat kabar dan majalah dalam periode ini. Berdasarkan atas solusi yang dimunculkan oleh perempuan, organisasi sosial-politik, dan negara tampak bahwa perkawinan bukanlah permasalahan yang sederhana. Dalam hal ini negara perlu hadir. Tentu saja hadirnya negara dalam hal ini penting dilihat, apakah negara hadir sebagai solusi atas permasalahan yang dihadapi perempuan ataukah negara menjadi kepanjangan tangan dari sebuah institusi negara yang selama ini secara kultural bias gender. Kondisi inilah yang tampaknya terjadi dalam periode 1920an hingga 1970an, bias gender dalam kehidupan perkawinan merupakan permasalahan yang terus menerus direproduksi oleh negara, sekalipun perempuan, baik secara individu maupun kolektif telah melakukan upaya dalam menegosiasikan permasalahan tersebut.

\section{DAFTAR RUJUKAN}

Abdoerachman, "Kinderhuwelijken" (Pernikahan dini), dalam Putri Mardika, IV, No. 8 (Agustus 1917), diambil dari Cora Vreede-De Stuers. 2008. Sejarah Perempuan Indonesia, Gerakan \& Pencapaian. Jakarta: Komunitas Bambu.
Amini, M.. "Biro Perkawinan dalam Keluarga Jawa Awal Abad ke20", dalam Sartono Kartodirdjo dkk. 2013. Sejarah Sosial: Konseptualisasi, Model, dan Tantangannya. Yogyakarta: Penerbit Ombak.

Berita Nasional, No. 272, Th. VI, 29 Juli 1976.

BPPIP. 1939. Boekoe Peringatan Konferensi Badan Perlindoengan Perempoean Indonesia dalam Perkawinan (BPPIP), 21-23 Juli 1939 di Maratam-Jogjakarta. Jogjakarta: BPPIP.

Geertz, H. 1982. Keluarga Jawa. Jakarta: Grafiti Pers

Haniwinoto, P. "Keadaan Perkawinan Perempuan Indonesia" dalam BPPIP. 1939. Boekoe Peringatan Konferensi Badan Perlindoengan Perempoean Indonesia dalam Perkawinan (BPPIP), 21-23 Juli 1939 di Maratam-Jogjakarta. Jogjakarta: BPPIP.

Indonesia Raya, No. 152, Th. VII, 6 Juli 1956.

Kartodirdjo, S. dkk. 1987. Perkembangan Peradaban Priyayi. Yogyakarta: Gadjah Mada University Presss.

Locher-Scholten, E. (ed.). 1992. Indonesia Women in Focus. Leiden: KITLV.

Nieuwenhuis, M.D. "Ibuism and Priyayization: Path to Power", dalam Elsbeth LocherScholten. 1992. Indonesia Women in Focus. Leiden: KITLV Press.

Pesat, 9 February 1939, Tahun pertama. No. 20. 
Soetomo, R. 1928. Perkawinan dan Perkawinan Anak2. Weltevreden: Balai Poestaka. Sosroatmodjo, A. dan Aulawi, A.W.. 1975. Hukum Perkawinan di Indonesia. Jakarta: Penerbit Bulan Bintang.

Sukarno. 1963. Sarinah, Kewadjiban Wanita dalam Perdjoeangan Republik Indonesia. Tjetakan Ketiga, Panitia Penerbit Buku- buku Karangan Presiden Sukarno.

Surya-Hadi, I.S. (ed.). 1959. Wanita, Pro dan Kontra Poligami. Semarang: Yayasan Gedung Wanita.

Suryakusuma, J. "The state and sexuality in New Order Indonesia". Dalam Laurie J. Sears, (ed.). 1996. Fantasizing the Feminine in Indonesia. Durham: Duke University Press. 